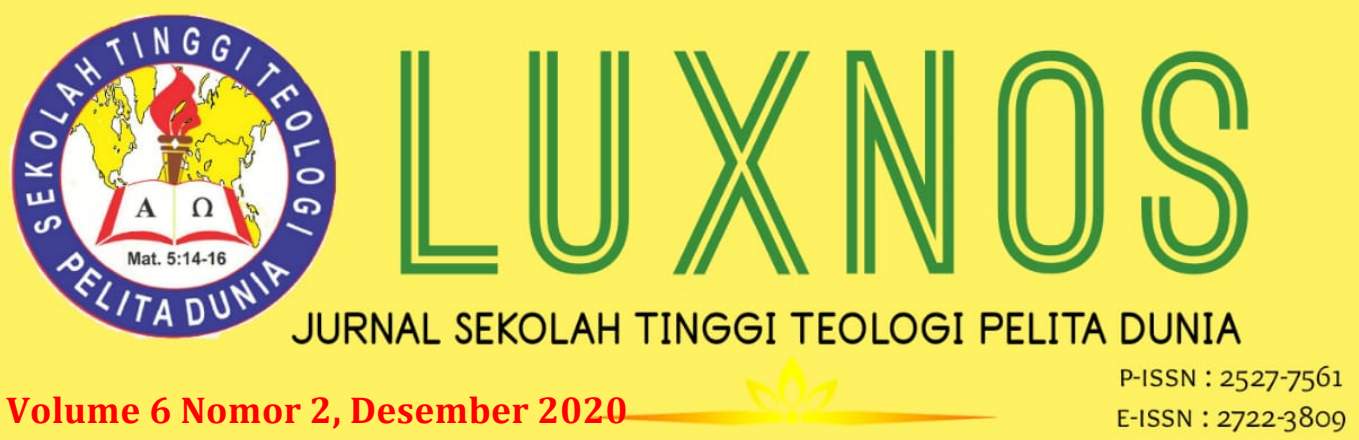

\title{
Aborsi Ditinjau Dari Perspektif Etika Kristen
}

\author{
Yosia Belo \\ Sekolah Tinggi Teologi Injili Arastamar (SETIA) Jakarta \\ byosia.belo@gmail.com
}

\begin{abstract}
This research is a qualitative study on abortion from the perspective of Christian faith. This research was conducted to provide academic arguments and scientific references for the Church against the rampant abortion practices and practices, especially in big cities including Jakarta. Using a qualitative approach, it is found that from a Christian ethical perspective, the act of abortion cannot be justified and chosen as an ethical decision because it contradicts or is contrary to the teachings of the Bible. Because God so loves human life and is even willing to send His only begotten Son, Jesus Christ, to redeem humans from sin. So that humans are not justified in ending the life of an innocent and wronged baby just for practical reasons.
\end{abstract}

Keywords: Abortion, Christian Ethics, Bible, Church

\begin{abstract}
Abstrak: Penelitian ini merupakan penelitian kualitatif terhadap aborsi ditinjau dari perspektif iman Kristen. Penelitian ini dilakukan untuk memberikan argumentasi akademis dan referensi ilmiah bagi Gereja terhadap maraknya tindakan dan praktik aborsi terutama di kota-kota besar termasuk Jakarta. Dengan menggunakan pendekatan kualitatif dijumpai bahwa dari perspektif etika Kristen, maka tindakan aborsi tidak dapat dibenarkan dan dipilih sebagai keputusan etis karena bertolakbelakang atau berlawanan dengan ajaran Alkitab. Karena Allah begitu mencintai kehidupan manusia bahkan rela mengutus Anak-Nya yang tunggal, yaitu Yesus Kristus untuk menebus manusia dari dosa. Sehingga manusia tidak dibenarkan mengakhiri kehidupan bayi yang tidak berdosa dan besalah hanya karena alasan-alasan yang praktis.
\end{abstract}

Kata Kunci: Aborsi, Etika Kristen, Alkitab, Gereja

\section{Pendahuluan}

Secara umum, aborsi dapat dipahami sebagai sebuah tindakan yang dilakukan dengan sengaja untuk mengakhiri janin dalam sebuah kandungan. Aborsi yang disengaja ini biasanya dilakukan dengan berbagai macam alasan. 
Misalnya, kehamilan karena pergaulan dan seks bebas, sehingga untuk menutupi dosa atau aib tersebut maka biasanya dilakukanlah aborsi. Sekalipun demikian, seringkali aborsi dilakukan karena pertimbangan faktor kesehatan.

Pengguguran kandungan atau aborsi (bahasa Latin: abortus) adalah berakhirnya kehamilan dengan dikeluarkannya janin atau embrio sebelum memiliki kemampuan untuk bertahan hidup di luar rahim, sehingga mengakibatkan kematiannya. Aborsi yang terjadi secara spontan disebut juga "keguguran". Aborsi yang dilakukan secara sengaja sering kali disebut "aborsi induksi" atau "abortus provokatus". Kata aborsi umumnya hanya digunakan dalam pengertian abortus provokatus. Prosedur serupa yang dilakukan setelah janin berpotensi untuk bertahan hidup di luar rahim juga dikenal dengan sebutan "aborsi tahap akhir".1

Pada kota-kota besar seperti Jakarta bahkan terdapat banyak klinik atau tempat yang menyediakan layanan untuk melakukan aborsi. Bahkan berdasarkan informasi yang diberikan oleh Kompas.com tanggal 18 Agustus 2020 yang lalu menyampaikan pemberitaan tentang sebuah klinik aborsi di Jakarta yang akhirnya terungkap dan tertangkap polisi. Bahkan dalam pemberitaan itu dijelaskan bahwa, "Berdasarkan hasil penyelidikan, praktik klinik aborsi itu telah beroperasi selama lima tahun. Namun, polisi hanya menemukan catatan jumlah pasien dalam satu tahun terkahir. Setidaknya ada 2.638 pasien aborsi yang tercatat sejak Januari 2019 sampai 10 April 2020. Berdasarkan data pasien tersebut, polisi memperkirakan ada 5 sampai 7 orang yang melakukan aborsi di tempat itu per hari". ${ }^{2}$

Berdasarkan informasi di atas, maka data aborsi yang diberikan sangat mencengangkan. Karena dalam kurun waktu satu hingga dua tahun saja pasien klinik aborsi tersebut dapat mencapai 2.638 orang. Dari data tersebut maka dapat dirata-ratakan 5-7 orang melakukan aborsi setiap hari. Ini baru satu klinik saja. Tidak dapat dibayangkan apabila ada 10 hingga 20 klinik yang sama dan beroperasi. Ada puluhan hingga ratusan janin yang digugurkan setiap hari.

Sekalipun data dan informasi di atas tidak secara spesifik mengungkap aborsi yang dilakukan oleh orang Kristen, namun tidak menutup kemungkinan bahwa dari ribuan pasien yang telah melakukan aborsi maka setidaknya terdapat 1 hingga $10 \%$ di antaranya adalah orang Kristen. Kalaupun kita ambil 1

\footnotetext{
1“Https://Id.Wikipedia.Org/Wiki/Gugur_kandungan\#: :Text=Pengguguran\%20kandun gan\%20atau\%20aborsi\%20(Bahasa,Spontan\%20disebut\%20juga\%20\%22keguguran\%22."

2 Muhammad Isa Bustomi, "Https://Megapolitan.Kompas.Com/Read/2020/08/18/20433181/Polisi-Klinik-Aborsi-DiRaden-Saleh-Diketahui-Warga-Sekitar-Dan-Pernah," Kompas. Com., 2020.
} 
\% saja, maka jumlah itu bukanlah jumlah yang harus membuat Gereja untuk "tutup mata" dan melakukan pembiaran.

Itulah sebabnya melalui penelitian ini, peneliti mencoba menilai, menganalisis serta memberikan pemahaman tentang aborsi berdasarkan konsep dan perspektif iman Kristen. Dalam hal ini tentunya berdasarkan ajaran dan pemahaman Alkitab. Dengan demikian, diharapkan dapat menjadi referensi bagi para pendeta, gembala, mahasiswa, aktifis hingga tenaga medis dalam lingkup kekristenan untuk melakukan tindakan preventif bahkan penanganan terhadap tindakan atau aktivitas aborsi.

\section{Metode Penelitian}

Metode penelitian yang digunakan dalam penelitian ini adalah metode kualitatif. Metode ini dipilih karena penelitian ini merupakan penelitian yang bertujuan untuk memperoleh data atau informasi kualitatif tentang aborsi ditinjau dari perspektif etika Kristen. Metode kualitatif yang digunakan dalam konteks ini adalah lebih kepada kajian pustaka atau tinjauan pustaka.

\section{Hasil Dan Pembahasan}

\section{A. Aborsi}

Pengguguran kandungan atau Aborsi adalah tindakan berakhirnya kehamilan dengan dikeluarkan hasil konsepsi (pertemuan sel telur dan sel sperma) sebelum janin atau embrio dapat hidup di luar kandungan, sehingga mengakibatkan kematiannya. Dalam dunia kedokteran ada 3 macam aborsi, yaitu: (1) Aborsi spontan atau alamiah berlangsung tanpa tindakan apapun, kebanyakan disebabkan karena kurang baiknya kualitas sel telur dan sel sperma. (2) Aborsi buatan atau sengaja adalah pengakhiran kehamilan sebelum usia kandungan 28 minggu sebagai suatu akibat tindakan yang disengaja dan disadari oleh calon ibu maupun si pelaksana aborsi (dokter, bidan atau sebagainya). (3) Aborsi terapeutik atau medis adalah pengguguran kandungan buatan yang dilakukan atas indikasi medis. Sebagai contoh, calon ibu yang sedang hamil tetapi mempunyai penyakit darah tinggi atau penyakit jantung yang parah yang dapat membahayakan baik calon ibu maupun janin yang dikandungnya. Tetapi ini semua atas pertimbangan medis yang matang dan tidak tergesa-gesa. ${ }^{3}$

Dalam penelitian ini, yang dikaji adalah jenis aborsi yang kedua. Di mana adanya tindakan yang dilakukan dengan kesadaran bahkan kesengajaan dengan berbagai macam alasan. Utamanya adalah karena alasan kehamilan di luar nikah, tidak menghendaki anak yang ada dalam kandungan hingga alasan-alasan yang

\footnotetext{
${ }^{3}$ Ayirin Ambat, “Apakah Aborsi Diperbolehkan Dalam Alkitab?," Kompasiana.
} 
lain. Mengapa hal ini yang menjadi konsen penelitian dari tulisan ini? Oleh karena aborsi jenis ini yang banyak dilakukan oleh masyarakat, khususnya di Indonesia. Sehingga melalui penelitian ini, dapat menjadi referensi akademis yang memberikan pemahaman yang baik kepada masyarakat gereja untuk senantiasa menerapkan prinsip-prinsip atau nilai-nilai iman Kristen.

Akan tetapi ada pula aborsi yang dilakukan dengan alasan untuk menyelamat nyawa sang ibu. Akan tetapi, apakah alasan tersebut dapat membenarkan tindakan setiap manusia menghilangkan nyawa bayi yang tidak bersalah. Sebenarnya problem seperti ini sudah pernah diteliti oleh Agus Ilan dan Jamin Tanhidy pada tahun 2014. Berikut dikemukakan oleh Ilan dan Tanhidy,

Meskipun kasus aborsi yang dilakukan dengan alasan demi keselamatan nyawa seorang ibu atau wanita yang sedang menghadapi proses persalinan bukanlah kasus yang baru (karena banyak negara di dunia saat ini sudah melegalkannya dan diatur oleh Undang-Undang), namun kasus ini tetap saja masih menjadi bahan perdebatan yang hangat, khususnya terkait "Hak Mencabut Nyawa Janin/Bayi" yang dikandung seorang wanita (apalagi kalau bayinya sehat dan layak untuk hidup). Kasus ini seolah-seolah menimbulkan dilema, mana yang hendak dipertahankan, nyawa Si Ibu atau Si Bayi (seperti makan buah Simalakama). ${ }^{4}$

\section{B. Prinsip-prinsip dalam Etika Kristen}

Secara Etimologi kata Etika berasal dari penggabungan kata Yunani Kuno: ethos ( $\eta \theta 0 \varsigma$, kata benda: berarti kebiasaan, adat) dan ethikos ( $\eta \theta$ เкós, kata sifat: berarti kesusilaan, perasaan batin atau kecenderungan hati seseorang ketika ia melakukan suatu perbuatan). Dengan demikian dapat dipahami bahwa etika memiliki arti timbul dari kebiasaan, yang menurut pengertian asli dapat dikatakan baik apabila sesuai dengan kebiasaan masyarakat. Lambat laun pengertian ini berubah menjadi suatu ilmu tentang perbuatan atau tingkah laku manusia yang dapat dinilai baik dan tidak baik; karena didalamnya mencakup analisis secara kritis, metodis, dan sistematis serta penerapan konsep seperti: benar, salah, baik, buruk dan tanggung jawab. ${ }^{5}$

Sumber utama etika adalah Alkitab yang menghasilkan etika Kristen. Etika Kristen berdasarkan kehendak-kehendak Allah seperti yang diwahyukan kepada manusia melalui Alkitab. Menurut Adi Putra, "Alkitab merupakan Firman Tuhan

\footnotetext{
${ }^{4}$ Agus Ilan and Jamin Tanhidy, "Tinjauan Terhadap Legalisasi Aborsi," Jurnal Simpson: Jurnal Teologi dan Pendidikan Agama Kristen 1, no. 2 (2016).

${ }^{5}$ Christie Kusnandar, "Sepuluh Perintah Tuhan Bagian Kedua: Kasih Terhadap Manusia Dalam Tinjauan Etika Kristen,” Jurnal Ilmiah METHONOMI 3, no. 2 (2017): 73-82.
} 
yang diwahyukan kepada manusia, ditulis dalam bahasa manusia". ${ }^{6}$ Karena Allah adalah Sang Pencipta dan yang mahakuasa, mahatahu dan kekal, etika Kristen bersifat mutlak, yaitu selalu benar, tidak bergantung kepada waktu, tempat dan lingkungan. Etika Kristen juga bersifat mengikat bagi umat-Nya, yaitu menuntut umat mematuhinya.

Pada Etika Kristen terdapat prinsip tentang hukum moral yang lebih tinggi karena adanya suatu kebaikan atau prinsip yang lebih tinggi daripada yang lain. Misalnya, manusia dituntut untuk mengasihi Allah lebih dari manusia ( $b d k$. Mat. 22: 36 - 38) bahkan dirinya sendiri. Bahkan Lukas 14: 26 juga menjelaskan, "Jikalau seorang datang kepada-Ku dan ia tidak membenci bapanya, ibunya, isterinya, anak-anaknya, saudara-saudaranya laki-laki atau perempuan, bahkan nyawanya sendiri, ia tidak dapat menjadi murid-Ku". Itulah sebabnya setiap orang Kristen dituntut untuk menerapkan prinsip ini, tidak dengan sembrono tetapi dengan dengan hati yang tulus dan iman kepada Yesus Kristus.

Etika Kristen juga mengajarkan supaya manusia lebih mengasihi sesama manusia lebih daripada materi ( $b d k$. Mat. 22: 39), termasuk harta, posisi, prestasi, nama, waktu, dan sebagainya. Bagi Alkitab mengasihi manusia adalah yang utama sedangkan materi adalah sekunder. Alam semesta dengan segala isinya dicipta Tuhan untuk dieksplor oleh manusia dan digunakan untuk kesejahteraannya (Kej. 1: 28). Sekalipun demikian, manusia dalam mengolah dan menguasai alam ciptaan Tuhan perlu menerapkan prinsip-prinsip kebenaran sesuai ajaran Alkitab.

Sebagai catatan, untuk menebus manusia dari akibat dosa, Allah rela mengirimkan Anak-Nya yang tunggal, Yesus Kristus, datang ke dunia, menderita bahkan mati di kayu salib yang hina. Karena Allah begitu mengutamakan manusia, orang percaya pun harus mengutamakan sesama manusia. Artinya kehidupan manusia jauh sangat penting dan berharga.

Berikut ini akan dikemukakan beberapa prinsip-prinsip yang berlaku dalam etika Kristen untuk menjadi pertimbangan guna menilai dan menindaklanjuti tindakan dan praktik aborsi berdasarkan etika Kristen.

Transparan (1Yoh. 1:7). Allah memiliki sifat yang terang dan di dalam terang tersebut tidak ada yang disembunyikan. Hal itu berlaku juga di dalam persekutuan, keterbukaan merupakan suatu hal yang harus diutamakan untuk terjalin persekutan yang baik sesuai dengan sejarah agama Kristen. Keterbukaan yang dilakukan di dalam komunitas merupakan awal dari munculkan kejujuran dan juga tetap adanya kepercayaan yang terjalin diantara anggota persekutuan

${ }^{6}$ Adi Putra, "Problematika Teks Dan Makna Matius 19: 9," Missio Ecclesiae 9, no. 2 (2020): 1-16. 
dan menjadi fokus dan tujuan iman Kristen. Dengan adanya keterbukaan maka anggota akan saling mendukung satu sama lain dan akan munculnya keharmonisan.

Tegas dalam Menegur Dosa (Ams. 27:6). Sahabat sejati seharusnya harus berani untuk saling menegur. Bahkan harus berani untuk "memukul" sahabatnya asalkan hal itu dimaksudkan untuk hal yang baik mengajarkan tentang manfaat berdoa bagi orang Kristen. Apabila memang teguran yang dilakukan bisa dengan memperhatian waktu dan jarak yang tepat, maka tidak perlu takut dan mengkhawatirkan untuk teguran tersebut akan memicu adanya jarak diantara kalian, dengan itu tidak perlu ada kekhawatiran kembali. Melakukan teguran untuk teman harus menggunakan cara yang baik, lalu pastikan untuk menegur sikapnya bukan pribadinya. Teguran itu juga ada tingkatannya, mulai dengan menegur untuk bertemu berdua langsung, dengan membawa 1-2 saksi, dan apabila jika tidak membuahkan hasil maka tegurlah di dalam forum perkumpulan.

Mengampuni (Mat. 18:21-35). Pada setiap persekutuan tidak jarang terjadi gesekan dan hendaknya dapat dijadikan gesekan tersebut untuk menajamkan diri untuk menjadi pribadi yang lebih baik lagi. Pengampunan dan kerendah hatian adalah cara paling tepat untuk dapat menerima perbedaan dan merupakan syarat penting untuk kita bisa bertumbuh. R.T. France mengatakan, "If the church is the community of the forgiven, then all its relationship will be marked by a forgiveness which is not a mere form of words, but an essential characteristic, from your heart excludes all casuistry dan legalism".7

Tidak menghakimi sendiri (Mat. 7:1; Gal. 6:1-2). Bagian ini (Mat. 7:1), Yesus sebenarnya mengajarkan bahwa orang Kristen tidak boleh menghakimi orang lain. ${ }^{8}$ Prinsip untuk tidak saling menghakimi menjadi prinsip yang utama dalam etika Kristen bahkan iman Kristen. Prinsip ini mengajak setiap orang Kristen untuk sampai kepada sebuah konsep dan pemahaman kepada setiap manusia untuk dapat saling menghargai dan menghormati satu sama lain. Tidak berusaha untuk mengambil dan mengkebiri setiap hak yang dimiliki oleh sesama manusia, yang adalah ciptaan Allah. Termasuk dalam hal mengakhiri hidup seorang bayi yang tidak bersalah dengan melakukan aborsi.

Penuh kasih (Efe. 4:32). Pada prinsip ini, setiap orang Kristen dituntut untuk senantiasa memberikan perlakuan yang sewajarnya kepada sesamanya. Dalam

7 R. T. France, The Tyndale New Testament Commentaries: Matthew (Surabaya: Momentum, 2007), 278.

${ }^{8}$ Kareasi H. Tambur M.K. Sembiring, Helen L. Miehle, P.G. Katoppo, Edward A. Kotynski, Bryan Hinton, ed., Pedoman Penafsiran Alkitab: Injil Matius, Kedua. (Jakarta: Lembaga Alkitab Indonesia, 2008), 181. 
hal ini dapat saling mengampuni, ramah terhadap yang lain dan penuh kasih mesra. Hal ini dilakukan dengan sebuah realitas bahwa orang Kristen telah terlebih dahulu menerima pengampunan dari Allah melalui Yesus Kristus.

Dapat membawa kedamaian (Rom. 14:19). Prinsip yang terakhir ini menjadi yang juga wajib dimiliki oleh setiap orang Kristen. Prinsip ini bertujuan untuk saling membangun satu sama lain. Berdasarkan ayat di atas, Th. van den End mengemukakan beberapa hal yang perlu dicatat,

(1) Membangun (membina) sesama orang percaya adalah menguatkan iman, berupaya supaya hubungannya dengan Tuhan semakin erat. (2) Saling membangun menyangkut juga seluruh jemaat. (3) Di sini kita diajar bahwa pembinaan jemaat bukan soal yang diatur "pihak atas". Bukan soal ceramah-ceramah yang diadakan oleh orang-orang pandai dari luar jemaat (meski bisa juga berguna). (4) Anjuran untuk saling membangun ini muncul dalam rangka uraian mengenai soal hubungan antar golongan 'kuat' dan golongan 'lemah' dalam jemaat. ${ }^{9}$

Demikianlah dapat dilihat beberapa prinsip yang ada dalam pengambilan keputusan dalam etika Kristen, yakni: transparan, tegas dalam menegur dosa, mengampuni, tidak menghakimi, penuh kasih dan dapat memberikan kedamaian. Semua hal ini merupakan hal yang sangat penting dan utama dalam etika Kristen. Selanjutnya Malcolm Brownlee memberikan beberapa sumber bantuan yang dapat diperhatikan oleh setiap orang Kristen supaya senantiasa dapat memelihara prinsip-prinsip di atas serta mengambil keputusan yang etis dan alkitabiah. Malcolm Brownlee menegaskan beberapa sumber, "Doa, Ibadah dan Roh Kudus; Gereja dan orang-orang lain; Alkitab; dan Bahan Bacaan". ${ }^{10}$

\section{Aborsi Ditinjau dari Perspektif Etika Kristen}

Etika Kristen merupakan prinsip yang didasarkan pada pengambilan keputusan untuk melakukan sesuatu dengan senantiasa memperhatikan prinsipprinsip yang diajarkan oleh Alkitab. Sedangkan menurut Brotosudarmo, "Ada tiga hal yang menentukan dalam pengambilan keputusan etika Kristen yaitu: 1) Doa, Ibadah dan Roh Kudus; 2) Gereja dan Persekutuan; 3) Alkitab".11 Ketiga hal ini menurut Brotosudarmo sangat mempengaruhi orang Kristen dalam pengambilan keputusan. Karena ketiga hal tersebut menjadi dasar dalam pengambilan keputusan bagi orang Kristen. Karena orang Kristen dalam

${ }^{9}$ Th. van den End, Tafsiran Alkitab: Surat Roma (Jakarta: BPK Gunung Mulia, 2006), 749.

10 Malcolm Brownlee, Pengambilan Keputusan Etis Dan Faktor-Faktor Di Dalamnya (Jakarta: BPK Gunung Mulia, 1987), 243-249.

11 R.M.D.S. Brotosudarmo, Etika Kristen Untuk Perguruan Tinggi (Yogyakarta: Penerbit ANDI, 2007), 81-82. 
pengambilan keputusan bukan seperti kaum pragmatisme yang mengutamakan manfaat dan tujuan dalam bertindak. Dan juga bukan berdasarkan hati nurani dalam pengambilan keputusan. Tetapi orang Kristen dalam pengambilan keputusan harus menyerahkan kepada Tuhan dalam arti berdoa dan memohon kepada Tuhan dan di dasarkan kepada kebenaran firman Tuhan. H. Harming mengatakan dalam penelitian terbaru yang dilakukannya,

"Menurut pandangan kaum Injili hal ini tidak dianggap benar. Alasannya, pertama, bayi yang ada dalam kandungan ibunya mengalami cacat, meskipun kemungkinan besar bahwa bayi yang dikandung mengalami tetapi dia berhak untuk hidup. Kedua, keluarga ini hidupnya berkekurangan, maka gereja, gembala dan orang Kristen berusaha untuk membantu keluarga ini. Ketiga, jika tidak melakukan aborsi maka keluarga tidak mampu menghidupi bayi tersebut dengan baik, meskipun tidak mampu menghidup bayi dengan baik tetapi tidak harus membunuh bayi tersebut. keempat, jika tidak melakukan aborsi terhadap anak tersebut hal itu dipandang sebagai keluarga yang membawa kutukan atau sial dan hal itu menjadi pergunjingan kaum keluarga atau masyarakat, hal itu belum tentu termasuk kutukan atau dosa, Alkitab mencatat dalam Injil Yohanes seperti berikut: "Murid-Murid-Nya bertanya kepada-Nya (Yesus): "Rabi, siapakah yang berbuat dosa, orang ini sendiri atau orang tuanya, sehingga ia dilahirkan buta? Jawab Yesus: "Bukan dia dan bukan juga orang tuanya, tetapi karena pekerjaan-pekerjaan Allah harus dinyatakan di dalam dia" (Yoh 9:2-3). Bahwa jelas sekali pandangan kaum Injili tidak menerima apapun alasannya mengenai aborsi dan hal itu melanggar perintah Tuhan (Kej 1:26-28,31)".12

Oleh karena etika Kristen didasarkan pada prinsip Alkitab, maka tentu seperti yang dikemukakan dalam kutipan di atas, maka tidak dapat dibenarkan seorang Kristen melakukan aborsi. Oleh karena jelas aborsi bertolak belakang dengan ajaran Alkitab. Apapun alasan pragmatis yang dilontarkan oleh setiap orang yang melakukan aborsi, namun satu hal yang paling penting dan paling utama yang harus senantiasa digarisbawahi adalah aborsi bertentangan dengan ajaran Alkitab.

Dengan melakukan aborsi maka sama halnya telah mengambil-alih hak dan kedaulatan Tuhan atas setiap makhluk ciptaan-Nya. Apabila Tuhan saja begitu mencintai dan mengasihi setiap kehidupan manusia di dalam dunia, sehingga Dia

12 H Harming, "Kajian Etis-Teologis Terhadap Pandangan Pragmatisme Tentang Tindakan Aborsi," Sabda: Jurnal Teologi Kristen 1, no. 1 (2020): 71-84. 
rela mengutus Anak-Nya, yaitu: Kristus ke dalam dunia untuk menebus. Dengan demikian, sebagai sesama ciptaan, setiap manusia tidak memiliki hak untuk menghilangkan nyawa seseorang termasuk dalam halnya ini adalah melakukan aborsi.

Norman L. Geisler mengatakan, “Perdebatan tentang aborsi berfokus pada keseluruhan persoalan kekudusan hidup manusia. Baik Kitab Suci maupun ilmu pengetahuan mendukung pandangan bahwa hidup manusia masing-masing dimulai pada saat pembuahan dan penyataan baik khusus maupun umum menyatakan bahwa membunuh seorang yang manusia yang tidak bersalah merupakan perbuatan yang salah". ${ }^{13}$

Dengan demikian hasil dari penelitian ini dapat ditemukan sebuah pendapat dan argumentasi bahwa aborsi merupakan sebuah tindakan yang bertolak belakangan dengan ajaran Alkitab dan kehendak Allah. Oleh karena itu praktik dan tindakan aborsi tidak dapat dibenarkan untuk dilakukan oleh setiap orang atau secara khusus oleh setiap orang Kristen.

\section{Kesimpulan}

Setelah melakukan penelitian terhadap aborsi ditinjau dari perspektif iman Kristen, maka diperoleh beberapa kesimpulan sebagai berikut:

Pertama, aborsi adalah tindakan pembunuhan bayi yang dilakukan secara sadar dan juga ada unsur kesengajaan untuk mengakhiri kehidupannya. Biasanya tindakan ini diambil untuk menutupi kesalahan yang telah dilakukan oleh pelaku atau bisa juga karena alasan-alasan yang lain.

Kedua, aborsi merupakan sebuah kejahatan dan dosa karena jelas sangat bertentangan dengan ajaran Alkitab. Alkitab mengajarkan tentang kehidupan manusia yang begitu dikasihi oleh Tuhan bahkan dengan rela Allah mengutus Anak-Nya yang tunggal, yakni: Yesus Kristus untuk menyelamatkan manusia dari dosa. Hal ini menunjukkan betapa hidup manusia begitu berharga bagi Allah.

Ketiga, aborsi tidak dapat dibenarkan dari perspektif etika Kristen. Oleh karena etika mengajarkan setiap orang Kristen untuk mengambil keputusan berdasarkan pertimbangan etis yang alkitabiah. Sedangkan aborsi sangat bertolak belakang dengan ajaran Alkitab.

\section{Referensi}

Ambat, Ayirin. “Apakah Aborsi Diperbolehkan Dalam Alkitab?” Kompasiana. Brotosudarmo, R.M.D.S. Etika Kristen Untuk Perguruan Tinggi. Yogyakarta:

${ }^{13}$ Norman L Geisler, Etika Kristen: Pilihan Dan Isu Kontemporer, Kedua. (Malang: SAAT, 2010),183. 


\section{JURNAL LUXNOS \\ Volume 6 Nomor 2, Desember 2020}

Penerbit ANDI, 2007.

Brownlee, Malcolm. Pengambilan Keputusan Etis Dan Faktor-Faktor Di Dalamnya.

Jakarta: BPK Gunung Mulia, 1987.

Bustomi, Muhammad Isa.

"Https://Megapolitan.Kompas.Com/Read/2020/08/18/20433181/Polisi-

Klinik-Aborsi-Di-Raden-Saleh-Diketahui-Warga-Sekitar-Dan-Pernah.”

Kompas. Com., 2020.

End, Th. van den. Tafsiran Alkitab: Surat Roma. Jakarta: BPK Gunung Mulia, 2006.

France, R. T. The Tyndale New Testament Commentaries: Matthew. Surabaya:

Momentum, 2007.

Geisler, Norman L. Etika Kristen: Pilihan Dan Isu Kontemporer. Kedua. Malang: SAAT, 2010.

Harming, H. "Kajian Etis-Teologis Terhadap Pandangan Pragmatisme Tentang Tindakan Aborsi." Sabda: Jurnal Teologi Kristen 1, no. 1 (2020): 71-84.

Ilan, Agus, and Jamin Tanhidy. "Tinjauan Terhadap Legalisasi Aborsi." Jurnal Simpson: Jurnal Teologi dan Pendidikan Agama Kristen 1, no. 2 (2016).

Kusnandar, Christie. "Sepuluh Perintah Tuhan Bagian Kedua: Kasih Terhadap Manusia Dalam Tinjauan Etika Kristen." Jurnal Ilmiah METHONOMI 3, no. 2 (2017): 73-82.

M.K. Sembiring, Helen L. Miehle, P.G. Katoppo, Edward A. Kotynski, Bryan Hinton, Kareasi H. Tambur, ed. Pedoman Penafsiran Alkitab: Injil Matius. Kedua. Jakarta: Lembaga Alkitab Indonesia, 2008.

Putra, Adi. "Problematika Teks Dan Makna Matius 19: 9." Missio Ecclesiae 9, no. 2 (2020): 1-16.

"Https://Id.Wikipedia.Org/Wiki/Gugur_kandungan\#: :Text=Pengguguran\%20k andungan\%20atau\%20aborsi\%20(Bahasa,Spontan\%20disebut\%20juga\%2 0\%22keguguran\%22." 